\title{
A Simple Chemical Method to Differentiate Mycobacterium from Nocardia
}

\author{
By F. KANETSUNA AND A. BARTOLI \\ Centre of Microbiology and Cell Biology, Instituto Venezolano de \\ Investigaciones Cientificas, Apartado 1827, Caracas, Venezuela
}

(Accepted for publication II October I97I)

\begin{abstract}
SUMMARY
A simple, rapid, chemical method to differentiate Mycobacterium from Nocardia is described. After saponification of bacteria in $2.5 \%$ (w/v) KOH in methanol + benzene $(\mathrm{I}: \mathrm{I}, \mathrm{v} / \mathrm{v})$ at $37^{\circ}$ for one day, crude mycolic acids of mycobacteria were precipitated by addition of an equal volume of ethanol to an ethereal solution of extracted lipids. Mycobacteria gave large amounts of white precipitates (about Io $\mathrm{mg} / \mathrm{g}$ wet whole bacteria) of m.p. between $45^{\circ}$ and $70^{\circ}$, whereas nocardias gave no precipitate or very small amounts of precipitates (less than $2 \mathrm{mg} / \mathrm{g}$ whole bacteria) which did not melt below $150^{\circ}$ or melted near $80^{\circ}$.
\end{abstract}

\section{INTRODUCTION}

Nocardias and rapidly growing mycobacteria are difficult to differentiate by their physiological and morphological characteristics alone (Uesaka, 1956; Gordon, I966; Tsukamura, 1970). The GC content of DNA is the same in both genera (Yamaguchi, I967) as are the chemical components of the bacterial walls (i.e. arabinose, galactose, alanine, glutamic acid and meso-diaminopimelic acid) which also show similar immunological cross-reactions (Cummins, I962; Kwapinski, 1964). However, both genera have characteristic lipids, i.e. mycolic acids in mycobacteria and nocardic acids (nocardomycolic acids) in nocardias (Azuma, Yamamura \& Fukushi, I968; Kanetsuna, I968; Amar-Nacasch \& Vilkas, I969; Acharya \& Goldman, 1970; Guinand, Vacheron \& Michel, 1970; Ioneda, Lederer \& Rozanis, 1970). Although rapid identification of these lipids requires specialized techniques (Lanéelle, Asselineau \& Castelnuovo, I965; Etémadi, I967; Lechevalier, Horan \& Lechevalier, I97I) which may not be available in all laboratories, we have developed a simple method which differentiates mycobacteria from nocardias, based on the demonstration of mycolic acids in mycobacteria.

\section{METHODS}

Mycolic and nocardic acids. Mycolic acids were isolated from the cell wall of Mycobacterium bovis BCG (Kanetsuna, 1968). Nocardic acids were obtained from bound lipids in the cell wall of Nocardia asteroides $\mathrm{r} 3 \mathrm{I}$, grown in Sauton medium for one week, as described by Guinand et al. (1970).

The solubility of both mycolic acids and nocardic acids in a mixture of ether and ethanol was determined by dissolving a sample $(20 \mathrm{mg})$ of either mycolic acid or nocardic acid in a small volume of ether and adding ethanol to make a total volume of $2 \mathrm{ml}$. (The ratio of ether to ethanol in the mixture varied from $\mathrm{I}: 0$ to $\mathrm{I}: 2, \mathrm{v} / \mathrm{v}$.) After $2 \mathrm{~h}$ at 0 to $4^{\circ}$, the precipitates were collected by centrifuging at about $200 \mathrm{~g}$ for $5 \mathrm{~min}$, dried and weighed. 
Organisms and growth conditions. The mycobacteria and nocardias used are listed in Table I. They were cultured, without shaking, on a heart infusion broth (Difco) containing $5 \%(\mathrm{w} / \mathrm{v})$ glycerol with or without I $\mu \mathrm{g}$ malachite green $/ \mathrm{ml}$ (medium I and II, respectively), or on a tryptose phosphate broth (Difco) containing $5 \%$ (w/v) glycerol (medium III) at $37^{\circ}$ for several days as indicated in Table I. Bacteria were killed in 2 to $3 \%$ formaldehyde, collected by centrifuging or filtering and washed with water.

Extraction of mycolic acids from bacteria. The procedure used was as follows. Bacteria ( $2 \mathrm{~g}$ wet wt) were saponified in a closed tube with $5 \mathrm{ml}$ of $2.5 \%(\mathrm{w} / \mathrm{v}) \mathrm{KOH}$ in methanol+ benzene $(\mathrm{I}: \mathrm{I}, \mathrm{v} / \mathrm{v})$ for one day at $37^{\circ}$ with occasional shaking. Three $\mathrm{ml}$ of $\mathrm{I} \mathrm{N}-\mathrm{HCl}$ were then added to the mixture followed by about $5 \mathrm{ml}$ of ether and the whole mixed well. After centrifuging ( $200 \mathrm{~g}$ for $5 \mathrm{~min}$ ) the clear ethereal layer was removed. Ether extraction was repeated three or four more times and the combined ether extracts were evaporated. The residue was extracted again with ether three times. The final ether extracts were evaporated to $\mathrm{I} \mathrm{ml}$, I $\mathrm{ml}$ ethanol was added and after $2 \mathrm{~h}$ at 0 to $4^{\circ}$ the white precipitates were collected by centrifuging and dried. These were redissolved in I $\mathrm{ml}$ ether and I to $2 \mathrm{ml}$ ethanol added. After several hours at 0 to $4^{\circ}$ the precipitates were collected by centrifuging, dried, weighed and the m.p. determined. (When the precipitates turned yellowish as has been seen in some strains of mycobacteria, reprecipitation was repeated once more as described above.)

\section{RESULTS AND DISCUSSION}

About $90 \%$ of mycolic acids from BCG were precipitated on adding $\mathrm{I}$ to $2 \mathrm{vol}$. of ethanol to I vol. of ethereal solution of mycolic acids. In ethanol +ether $(\mathrm{I}: 2, \mathrm{v} / \mathrm{v})$, about $75 \%$ of mycolic acids were precipitated. Nocardic acids from Nocardia asteroides remained dissolved in ethanol + ether (from $\mathrm{I}: 2, \mathrm{v} / \mathrm{v}$ to $2: \mathrm{I}, \mathrm{v} / \mathrm{v}$ ).

The yield of the precipitate of mycolic acids from BCG depends on the volume of ethanol+ ether. Using $20 \mathrm{mg}$ of mycolic acids, about $90 \%$ was precipitated in I or $2 \mathrm{ml}$ of ether+ ethanol (I:I, v/v), whereas only about 85 and $30 \%$ of mycolic acids were precipitated in 4 and $6 \mathrm{ml}$ respectively. Large volumes of ether + ethanol must therefore be avoided.

The above procedures applied to various mycobacteria and nocardias showed that only mycobacteria gave large amounts of white precipitates (Table I). Generally, about $10 \mathrm{mg}$ of the precipitates were obtained from I $g$ (wet wt) of mycobacteria with a m.p. between $45^{\circ}$ and $70^{\circ}$ which corresponds with published data (Asselineau, 1966). Since the rate of synthesis of mycolic acids parallels the growth of mycobacteria (Bennet \& Asselineau, 1970), this amount of mycolic acid fraction is probably constant during growth. Furthermore, as the mycolic acid-arabinogalactan-mucopeptide complex may be an essential structure of all mycobacterial walls (Kanetsuna, 1968), the mycolic acid content in the cell wall may not be greatly influenced by culture conditions.

Several mycobacteria gave no precipitates of mycolic acids but all belonged to $\mathrm{Myco}$ bacterium rhodochrous; two of these strains (no. 549 and 1256 ) were, in fact, originally classified in the genus Nocardia (Gordon, 1966). In the present study, all strains of $M$. rhodochrous were non-acid-fast. Lanéelle et al. (1965) and Lechevalier et al. (I97I) reported that $M$. rhodochrous does not contain mycolic acids but nocardic acids and that $M$. rhodochrous should be classified as Nocardia. We agree with their conclusion.

Species of Nocardia gave either no precipitate at all or just a small amount; i.e. less than $2 \mathrm{mg} / \mathrm{g}$ whole bacteria. However, the brownish precipitates of some nocardias did not melt below $150^{\circ}$, indicating that they were not mycolic acids. The precipitates of a few nocardias 
Table I. Precipitates of lipids of mycobacteria and nocardias in ether + ethanol $(\mathrm{I}: \mathrm{I}, v / v)$

\section{Organism*}

Mycobacterium avium Jucho

M. bovis $\mathrm{BCG}$

M. bovis MR

$M$. bovis USHI IO

$M$. bovis USHI RO

M. fortuitum

M. phlei

M. rhodochrous 549

M. rhodochrous 1256

M. rhodochrous 3406

M. rhodochrous 3407

M. rhodochrous 8036

M. rhodochrous NCTC 81 39

M. smegmatis ATCC 607

M. smegmatis ATCC 607

M. smegmatis ATCC I4468

M. tuberculosis $\mathrm{H} 37 \mathrm{Ra}$

M. tuberculosis $\mathrm{H} 37 \mathrm{Ra}$

$M$. tuberculosis AOYAMA B

$M$. sp. RABINOWITCH

$M$. sp. 521

$M$. sp. 521

$M$. sp. PI

Nocardia asteroides 10

N. asteroides 72

$N$. asteroides 73

$N$. asteroides $8 \mathbf{I}$

N. asteroides 93

$N$. asteroides 94

$N$. asteroides 123

$N$. asteroides 126

$N$. asteroides 127

$N$. asteroides 129

$N$. asteroides 131

$N$. asteroides 132

$N$. asteroides 155

$N$. asteroides 156

$N$. asteroides 166

$N$. asteroides 166

$N$. asteroides 205

N. brasiliensis $\mathbf{1 4 5}$

N. brasiliensis 168

N. brasiliensis 197

N. brasiliensis 198

N. brasiliensis 199

$N$. brasiliensis 201

N. brasiliensis $85 \mathrm{I}$

N. brasiliensis $5 \mathrm{I} 3$

N. brasiliensis 1548

$N$. caviae $\mathrm{I} 80$

N. sp. 244

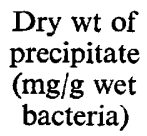

M.p. of precipitate
51 to 54

52 to 55

46 to 49

48 to 50

53 to 55

60 to 63

51 to 53

I

III 4

III 3

III 3

III 4

III 3

I 5

III 5

$\begin{array}{lr}\text { I } & \text { I4 }\end{array}$

IV 30

IV 30

I 7

I

III

IV

II

II

II

II

III

III

II

II

III

IV

III

III

III

I

III

II

II

III

II

II

II

III

II

III

III

II
I3

II

I 3

7

I 2

0

o

o

o

o

9

9

I5

IO

8

I 4

IO

8

9

I 2

I. 6

0

0.6

0

2.

2.0
0

0

0

0

0

0

0.3

0

0.4

I 7

$$
0
$$

0

o

0

0

0.7

0$$
\stackrel{1}{2} \cdot
$$

I 0

o
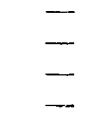

64 to 65

64 to 65

57 to 60

59 to 62

56 to 58

53 to 56

60 to 63

65 to 66

64 to 65

52 to 54

77 to 79

80 to 82

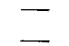

$>$ I 50

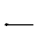

$-$

-

76 to 78

$>$ I 50

$>$ I 50

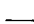

-

-

80 to 82

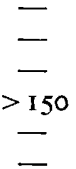

* Where a number is given following a species, this refers to the collections of Dr N. M. McClung (University of South Florida, U.S.A.) and Dr I. Uesaka (Chest Disease Research Institute, Kyoto University, Japan) who use the same reference number for their strains.

$\dagger \mathbf{A}=$ strains kept in our laboratory. $\mathbf{B}=$ given by Dr J. A. Serrano, Universidad de Los Andes, Venezuela, originally received from $\mathrm{Dr}$ N. M. McClung, except for $N$. brasiliensis no. 1548 (from $\mathrm{Dr}$ Mackinnon, Uruguay), N. brasiliensis no. $5 \mathrm{I} 3$ (from Dr Lacaz, Brazil) and all strains of M. rhodochrous (from Dr Gordon, Rutgers University, U.S.A.). C = given by Dr M. Nishiura, Leprosy Research Laboratory, Kyoto University, Japan. $\mathbf{D}=$ given by $\mathrm{Dr} \mathrm{I}$. Uesaka. $\mathrm{E}=$ received as lyophilized organisms from $\mathrm{Dr}$ I. Azuma, Osaka University, Japan. Nocardid asteroides no. I3I was originally obtained from Dr I. Uesaka.

$\ddagger$ Medium $I=$ heart infusion broth (Difco) containing $5 \%(\mathrm{w} / \mathrm{v})$ glycerol, and $0.000 \mathrm{I} \%(\mathrm{w} / \mathrm{v})$ malachite green. II $=$ heart infusion broth (Difco) containing $5 \%(\mathrm{w} / \mathrm{v})$ glycerol. III $=$ tryptose phosphate broth (Difco) containing $5 \%(\mathrm{w} / \mathrm{v})$ glycerol. IV = Sauton's medium. 
had a m.p. near $80^{\circ}$. These might be saturated nocardic acids which are present in some strains of nocardia (Asselineau, I966; I. Yano, personal communication). We propose, therefore, that to determine if a strain is a mycobacterium, the precipitate should be at least $5 \mathrm{mg} / \mathrm{g}$ wet whole bacteria and its m.p. be between $45^{\circ}$ and $70^{\circ}$.

The differences in the results obtained from mycobacteria and nocardias are not caused by different culture media, since some mycobacteria and nocardias cultured in medium I gave similar results to the same bacteria cultured in medium III. A few strains of other genera were also examined. Bacillus cereus 569, Escherichia coli $\mathrm{Hfr} \mathrm{C} 6$ and Micrococcus lysodeikticus which were cultured for $16 \mathrm{~h}$ at $37^{\circ}$ in a Penassay broth (Difco) with continuous shaking did not give precipitates. Streptomyces albus G cultured at room temperature for 4 days in a heart infusion broth (Difco) with shaking gave no precipitates.

We thank Dr J. A. Serrano and Dr I. Uesaka for mycobacteria and nocardias, and Dr I. Yano for nocardias and authentic nocardic acids. We acknowledge the contribution of Dr M. Nishiura and Dr I. Azuma who provided mycobacteria and permission to do a part of the experiments in their laboratories.

\section{REFERENCES}

ACHARYA, P. V. N. \& Goldman, D. S. (I970). Chemical composition of the cell wall of the $\mathrm{H}_{37} \mathrm{Ra}$ strain of Mycobacterium tuberculosis. Journal of Bacteriology 102, 733-739.

AmAR-NACASCH, Cl. \& VilKas, E. (I969). Étude des parois d'une souche humaine virulente de Mycobacterium tuberculosis (I). Préparation et analyse chimique. Bulletin de la Société de chimie biologique 5I, 61 3-620.

Asselineau, J. (1966). The Bacterial Lipids. Paris: Hermann.

Azuma, I., YamamuRA, Y. \& FuKUSHI, K. (1968). Fractionation of mycobacterial cell wall. Isolation of arabinose mycolate and arabinogalactan from cell wall fraction of Mycobacterium tuberculosis strain Aoyama B. Journal of Bacteriology 96, 1885-1887.

BenNet, P. \& Asselineau, J. (1970). Influence de l'âge sur la teneur en acides gras à chaine remifiée du bacille tuberculeux. Annales de l'Institut Pasteur 118, 324-329.

Cummins, C.S. (1962). Chemical composition and antigenic structure of cell walls of Corynebacterium, Mycobacterium, Nocardia, Actinomyces and Arthrobacter. Journal of General Microbiology 28, 35-50.

ETÉMADI, A. H. (1967). The use of pyrolysis gas chromatography and mass spectroscopy in the study of the structure of mycolic acids. Journal of Gas Chromatography 5, 447-456.

GoRDON, R. E. (1966). Some strains in search of a genus-Corynebacterium, Mycobacterium, Nocardia or what? Journal of General Microbiology 43, 329-343.

Guinand, M., Vacheron, M. J. \& Michel, G. (I970). Structure des parois cellulaires des nocardia. I. Isolement et composition des parois de Nocardia kirovani. Federation of European Biochemical Societies Letters 6, 37-39.

IONEDA, T., LEDERER, E. \& RozANIS, J. (1970). Sur la structure des diesters de tréhalose ('cord factors') produits par Nocardia asteroides et Nocardia rhodochrous. Chemistry and Physics of Lipids 4, 375-392.

Kanetsuna, F. (1968). Chemical analyses of mycobacterial cell walls. Biochimica et biophysica acta $\mathbf{1 5 8}$, I30-I43.

KWAPINSKI, J. B. (1964). Antigenic structure of the Actinomycetales. VII. Chemical and serological similarities of cell walls from 100 Actinomycetales strains. Journal of Bacteriology 88, I21 I-I 219.

Lanéelle, M. A., Asselineau, J. \& Castelnuovo, G. (1965). Études sur les mycobactéries et nocardiae. IV. Composition des lipides de Mycobacterium rhodochrous, M. pellegrino sp., et de quelques souches de nocardiae. Annales de l'Institut Pasteur 108, 69-82.

Lechevalier, M. P., Horan, A. C. \& Lechevalier, H. (I971). Lipid composition in the classification of Nocardiae and Mycobacteria. Journal of Bacteriology 105, 313-318.

Tsukamura, M. (1970). Relationship between Mycobacterium and Nocardia. Japanese Journal of Microbiology 14, I87-195.

UesAKA, I. (1956). Taxonomic studies on Mycobacterium and Nocardia. I. Utilization of amino acids on Pridham and Gottlieb's synthetic solid media. Japanese Journal of Tuberculosis 4, I-10.

YAMAGUCHI, T. (1967). Similarity in DNA of various morphologically distinct actinomycetes. Journal of General and Applied Microbiology 13, 63-71. 